\title{
Towards an “Actor-Network Theory” Perspective in Education and Research-Affirmative Action in America: How to Teach a Controversy?
}

\author{
Eric Agbessi, Pierre Mathieu \\ Université Blaise Pascal, Clermont-Ferrand, France
}

\begin{abstract}
The main goal of this article is to explain how a new pedagogical project has been defined and implemented to teach concepts, such as Affirmative Action to master students. Indeed, instead of providing a classical teaching on intercultural matters centered on the teachers course, we try to get students as much as possible involved in the teaching process and make them work on their creativity in class. Our purpose is then to implement a new pedagogical model of teaching based on an Actor-Network Theory approach developed in three ways: 1. Bring the students not to consider Affirmative Action as spectators any more but as actants (from sense to sensitivity); 2. Think about Affirmative Action in terms of associations (not only knowledge but also multidimensional and dynamic sets of skills and competencies combining multidisciplinary approaches); and 3. Help the students develop critical approaches by taking them to consider matters of concern rather than matters of fact. Examples are eventually given to highlight and set in context this theoretical approach from an “Actor-Network Theory” perspective.
\end{abstract}

Keywords: Affirmative Action, Actor-Network Theory, pedagogy, intercultural human resources

\section{Introduction}

Over the last three years, the Americans have been celebrating the 50th anniversary of the Civil Rights Acts and the most important events of the civil rights movement, notably Dr. Martin Luther King's "I Have a Dream" speech that has been praised around the world ever since it was made.

In our master's “Intercultural Human Resources” programs, students attend classes in American civilization. It is an important part of their syllabus. Since it is a time of celebration in America, showing this country's ability to overcome difficulties in terms of citizenship, the decision was made to use the passage of the Civil Rights Acts of 1964 and 1965 to work on the laws that were then adopted by the American Congress and study their impact on the American daily life. The focus was on Title VII of the 1964 legislation, known as "Affirmative Action" and used to promote minorities and their recruitment by American companies.

Affirmative Action has been a controversial issue ever since its conception. In 1964, Southern congressmen bitterly opposed on the adoption of Title VII of the Civil Rights Act, which was the main bone of contention between the proponents and opponents of the law. The Philadelphia Plan launched by the

Eric Agbessi, Ph.D., associate professor, dean, Faculty of Applied Languages, Research Laboratory: Communication and Solidarity (EA 4647), Blaise Pascal University.

Pierre Mathieu, Ph.D., associate professor, deputy dean, Faculty of Applied Languages, Research Laboratory: CRCGM (EA 3849), Blaise Pascal University. 
Republicans in the early 1970s in an attempt to get a more diverse body in companies was another cause of major discontent in America. At that time, the political choice made by American universities to recruit minority students, keeping a certain percentage of positions for them, led to fierce debates among faculty staff as well as among students. Bakke, a white student who had been denied the right to register at the University of California in Los Angeles (UCLA), sued the Board of Regents and won his case at the Supreme Court. It was the first of many judiciary events to put an end to Affirmative Action. State actions have also been undertaken to legally oppose the use of Affirmative Action locally.

Over the years, American presidents have adopted different strategies, either supporting this way of integrating minorities or being firmly opposed to it. For instance, if Nixon's Administration implemented the Philadelphia Plan, Ronald Reagan, a staunch Republican too, did his best to dismantle Affirmative Action based programs.

Minorities have always sought to get an economic integration and have acted consequently, marching, demonstrating in an attempt to assert their rights. During the civil rights era, under the leadership of Dr. Martin Luther King Jr., the African-Americans addressed the socioeconomic issues. In September 1963, the speech made by the Baptist Minister in Washington D.C. in support of the passage of the Civil Rights Act was also an attempt to make a critical analysis of the inequalities in terms of employment, housing, and voting rights.

In class, our master students are taught the main lines of the history of the civil rights movement and of the Civil Rights Act. They are invited to read the most important pieces of legislation as well as the most important speeches made in support of or in opposition to the civil legislation. They work on their own on the legal websites like the Equal Employment Opportunity Commission (EEOC), the agency of the American government that enforces the federal employment discrimination laws, and on the communication done by companies to promote diversity in their business fields.

The first two weeks of their term are dedicated to this work. After another class spent on debating over the main issues at stake, the students are then ready to work on the most important controversy, i.e., the intent to promote diversity thanks to Affirmative Action while maintaining equality as defined in the American Constitution. Indeed, the contradiction that may exist between forcing the implementation of diversity and promoting equality for all is at the core of their work.

Therefore, students have to understand and analyze the major disagreements on the issue and the strategies used to either support or put an end to Affirmative Action. They are also liable to learn the rules or methods defined in terms of organization favoring the development of such a project or, on the contrary, put an end to it. They have to know the kind of tools used to measure the level of diversity achieved on the staff. Finally, students work on concepts such as heterogeneity in the workplace, heterogeneity in Human Resources Management, and weaknesses in management strategy to fully understand the potential evolutions of companies in that field. When they look into the details of managing diversity, they virtually face "managerial controversies" in which managers disagree but are able to understand the reasons of their disagreement. Indeed, as Hussenot (2014) wrote:

Generally speaking, the concept of controversy can be seen as the pragmatic side of the Actor-Network Theory. Developed from ethnographical studies (...) and case studies (...), this concept aims to understand activities, such as scientific research, as well as the innovations and politics that result from controversies among actors. More precisely, Callon (1986) defines controversy as any dissident action that calls into question the relations between the heterogeneous elements (humans, materiality, etc.) in the networks. Controversies emerge when actors question and discuss things that 
had previously been taken for granted, such as habits, practices, etc. (Venturini, 2010). Inspired by this concept, Actor-Network Theory researchers have argued that by analyzing controversies, we can better understand the everyday practices, the associations between heterogeneous elements, and the production of facts and discourses. (Latour, 2005)

Students who major in master in "Intercultural Resources Management" will inevitably have to study managerial controversies in their worklife, such as the ones associated with the implementation of Affirmative Action. It will not be just a matter of studies, it will be something they will have to face and sometimes cope with. Our goal is then to develop the most effective educational methods to help students develop skills allowing them to overtake the "matters of facts" (indisputable facts considered as definitively determined and stable) to reach the "matters of concern” (Latour, 1984).

Reality is not defined by matters of fact. Matters of fact are not all that is given in experience. Matters of fact are only very partial, and I would argue, very polemical, very political renderings of matters of concern and only a subset of what could also be called states of affairs. (Latour, 1984, p. 232)

\section{Towards a New Teaching Model?}

Working on matters of concern instead of concentrating on matters of fact as we usually do corresponds to a new teaching model and inevitably leads to new methods of evaluation knowing that these students are about to enter the labor market.

Therefore, during this second year in masters, evaluation is not just a common exercise aiming at testing a basic knowledge. It could rather be seen as being part and parcel of the transitional period between the years they have spent at the university and their first jobs.

Since their major is intercultural management, they also have to get familiar with Gardner's theories on multiple intelligences (Gardner, 2011). Understanding matters of concern requires the reading of the book of this renowned psychologist since students will necessarily have to adopt a new strategy in terms of general communication on this issue. The easiest way we have found to come to terms with this is a dual strategy. First, the teacher has to play a different role as we will see in the following paragraphs. Second, he/she will not only work with them in a different way, but he/she will also have to make them present their work in a perspective that corresponds to matters of concern. In other words, he/she will have to go from a presentation and analysis of the legislation and its consequences (matters of fact) to some work on how people, minorities in particular, feel about the law (matters of concern). Sensitivity is the distance that may exist between what is legally commonly accepted and shared and the claims of those who think that this law has not been made for them. This distance is the line connecting two distant and antagonistic points which can be defined as follows.

We propose to describe the pedagogical model usually used in our French master level classes from an “agonistic-antagonistic” point of view. Bernard-Weil (1992) defined “agonistic-antagonistic systems” as follows:

The two elements of the couple act from an antagonistic (ANT) point of view, i.e., by actions in opposite directions on some receptors, and from an agonistic (AG) point of view, i.e., by actions in the same directions on other receptors. (p. 47)

Our description relies on the analysis of three main couples:

1. The central role of the teacher: In this classical framework, the teacher is the key player of the educational process. In his/her face-to-face classes, he/she expects students to be deeply involved and to play an active role in his/her teaching. In an ago-antagonistic point of view, the two poles are on one side the professor and on the other one the students. Both of them are supposed to combine their efforts towards the same goal 
and resist opposite strengths. The cursor is however clearly located on the side of the professor who is supposed to totally master the process of learning. The work done in that case is centered on sense (see Figure 1).

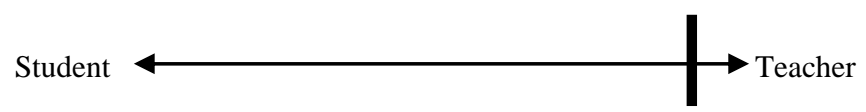

Figure 1. Teacher's and student's respective roles.

2. The central object of analysis is knowledge: As a consequence of the previous ago-antagonistic couple, we also analyze that the main object of the teaching process is a set of knowledge. Knowledge is indeed an asset, the teacher is supposed to own and the students are supposed to learn. The aim of the educational process is how this transfer can be successful. But, even if such a process is often successful, we consider that it is not as successful as it can be with undergraduate students because of the way the class objectives are defined. So, using the same figure as previously, we aim at shaping this second ago-antagonist couple, as shown in Figure 2.

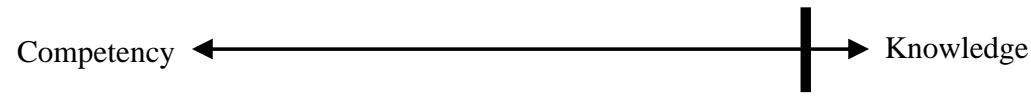

Figure 2. Knowledge vs. competency.

3. Knowledge stemming from monodisciplinarity: The third point of our analysis is about the central place of monodisciplinarity in our syllabus. We form the hypothesis that the two previous ideas enforce a disciplinary approach of education. Each and every professor, as a specialist of his/her own field, builds his/her "ivory tower" and teaches his/her class without any connection with his/her colleagues'. There is actually little incentive to implement interdisciplinary programs (see Figure 3).

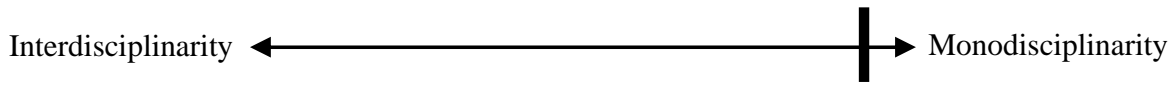

Figure 3. Monodisciplinarity vs. interdisciplinarity.

The model here above mentioned is ill-adapted to the complexity of teachings at such a level, i.e., master's degrees. We indeed share some intuitions based both on our educational experience and on expectations in terms of skills and employability of our students. Initiating such a project, that is to say, teaching such a class in an Actor-Network Theory perspective, requires some prerequisites:

1. We share the common view that teaching cannot be limited to sharing knowledge. Students have to evolve from basic knowledge as typically acquired in a class to adequate competencies they manage to reach in such a class or during internships. Teachers are therefore organizers of pedagogical programs on diversity with a specific goal, using the class to develop new strategies in terms of apprenticeship.

2. These new strategies can be defined as students' ability to become actors of their training, facing complex societal issues. They are expected to deal with thorny problems and to do so, they have to make the difference between what is related to sense (legal matters, business rules, and managerial strategies) and what stems from sensitivity (how people feel when Affirmative Action is implemented or when an end is put to an Affirmative Action program).

3. We are also convinced that students who are specialists in Human Resources Management need to work on an interdisciplinary basis. Engineering Intercultural and International Human Resources Projects require indeed to mobilize not only very numerous and varied technical skills (legal, strategic, managerial, communicational, etc.), but also an ability to continuously imagine and build complex innovative solutions. 
The purpose is then to implement a new pedagogical model of teaching based on an Actor-Network Theory approach developed in three ways:

1. Bring the students not to consider Affirmative Action as spectators any more but as actants (from sense to sensitivity);

2. Think about Affirmative Action in terms of associations (not only knowledge but also multidimensional and dynamic sets of skills and competencies combining multidisciplinary approaches);

3. Help the students develop critical approaches by taking them to consider matters of concern rather than matters of fact.

Based on such key assumptions, we decided to redefine programs leading the students to become real actors of their own learning process (see Figure 4, Arrow 1). As actors of their own representations about Affirmative Action, the students have "naturally" overtaken the single field of "knowledge" to develop complex operational competencies (Arrow 2) matching different disciplinary perspectives (Arrow 3).

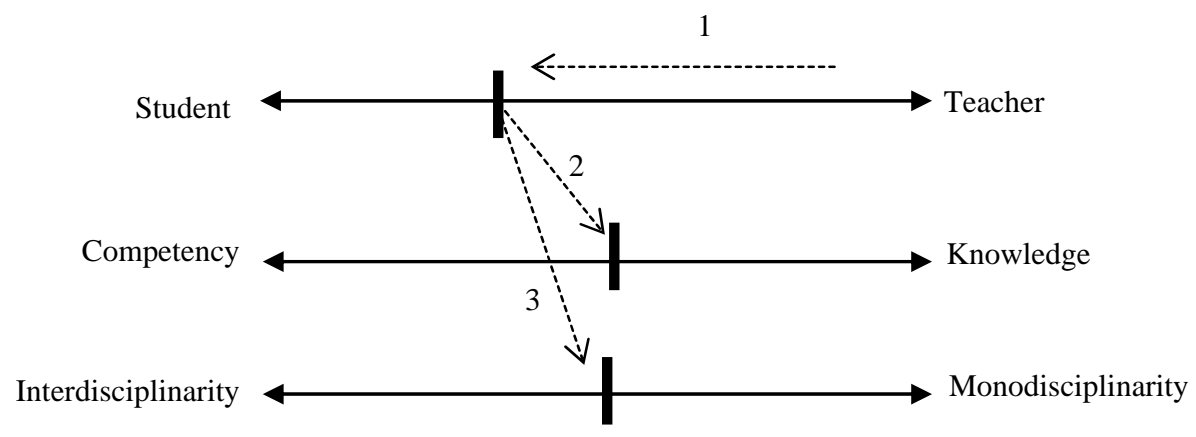

Figure 4. An Actor-Network Theory based model for education.

\section{Some New Pedagogical Practices Based on This Model}

\section{Formal Evaluation}

Students are evaluated twice at the end of the session. The first one is on what has been defined as "sense" at the beginning of this article. That is to say, they have to write a short memoir (5-10 pages) on an account of the legislation or on a way an American company implements Affirmative Action, or on the communication strategies of a company in terms of diversity. In this work, they have to show their mastering of key concepts and their ability to analyze current professional situations of the daily life. Their expertise at combining different disciplines in their demonstrations is highly praised by evaluators. For instance, students who are able to present their project in an international perspective, showing the differences in terms of management while displaying the local impact of the policies implemented, will get a better grade than students who strictly limit their study to a specific company with a restricted goal as far as diversity is concerned.

\section{Evaluation Based on Sensitivity}

The second evaluation is on free will basis. What matters is their ability not only to master key concepts, but also present an analysis of diversity or of the civil rights legislation in a personal way. They have to use their own tools — mainly information and communications technology (ICT) — to create something presenting a personal account of what they think about such programs or how they contemplate their potential evolution. Students are given such an opportunity, because we (the teachers in charge of this course) want them to illustrate the course content while expressing their feelings about the issues at stake in this class. What do they 
think about quotas? How do they feel about the racial divide in America? What is the right movie, the right show to illustrate such programs? How would they define discrimination in terms of employment? ...

Students appear to be very creative and willing to express their own views on such thorny questions. It takes them some time to define their project that must be collective since we want them to work in groups of four to five people. We also pay a lot of attention to the way people decide to work together. Since students come from all around the world, we make them work on an international basis.

Here are four examples of the work they managed to produce:

1. Draw my life: Some students decided to use this Internet meme to present their way of interpreting job discrimination against the Latinos in the United States of America. The video was shot in fast-motion photography of a figure drawn on a whiteboard. It was the story of a poor Latina whose lack of fortune led to one job interview to another until she managed to create her own company out of despair. In that case, sense is the equal protection of people under the law, but sensitivity is expressed by the feeling of being discriminated against. Antagonism is presented through the difficulties of finding a job when you belong to a minority, a problem confirmed by the information found on the EEOC Website.

2. Seven-second videos: A group of students worked on a series of videos lasting seven seconds called humor vines and showing how communities use such a technology to make fun of each other or of themselves. How do Black and White people knock on a door? How do they dunk? What do they do when the police arrive? They based their intercultural analyses on the comparisons drawn by the authors. In this second example, sense is that everyone is the same under the law but this sameness does not resist the acid test of the intercultural specificity of American society.

3. Acting on stage: Another group wrote a play with a play writer and after a three-month period of rehearsals, they performed on stage in front of a public audience including first year master students and undergraduate ones. They entitled the play Meeting Pot. Sense was then expressed on stage through art, the sensitivity of each character being voluntarily highly dramatized (see Figure 5).

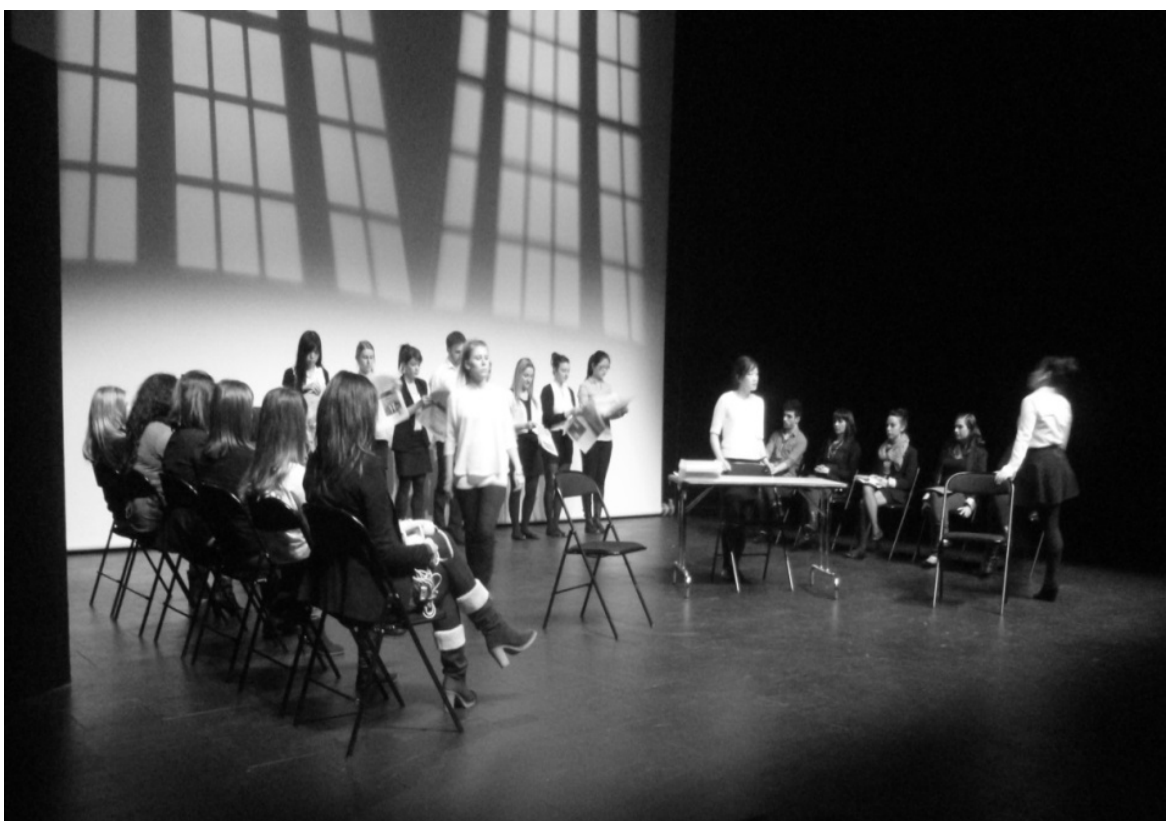

Figure 5. First scene of the play Meeting Pot. 
4. Writing an article for a professional journal: Students worked on Affirmative Action in different parts of the world. The brochure they managed to write was not only a gathering of the most important examples of such a political project around the world, it was also a way of showing how it was illustrated by cartoonists in the press and of presenting different testimonials (see Figure 6). Sense was the law, sensitivity was expressed by the journalists' opinions and the way they were illustrated.

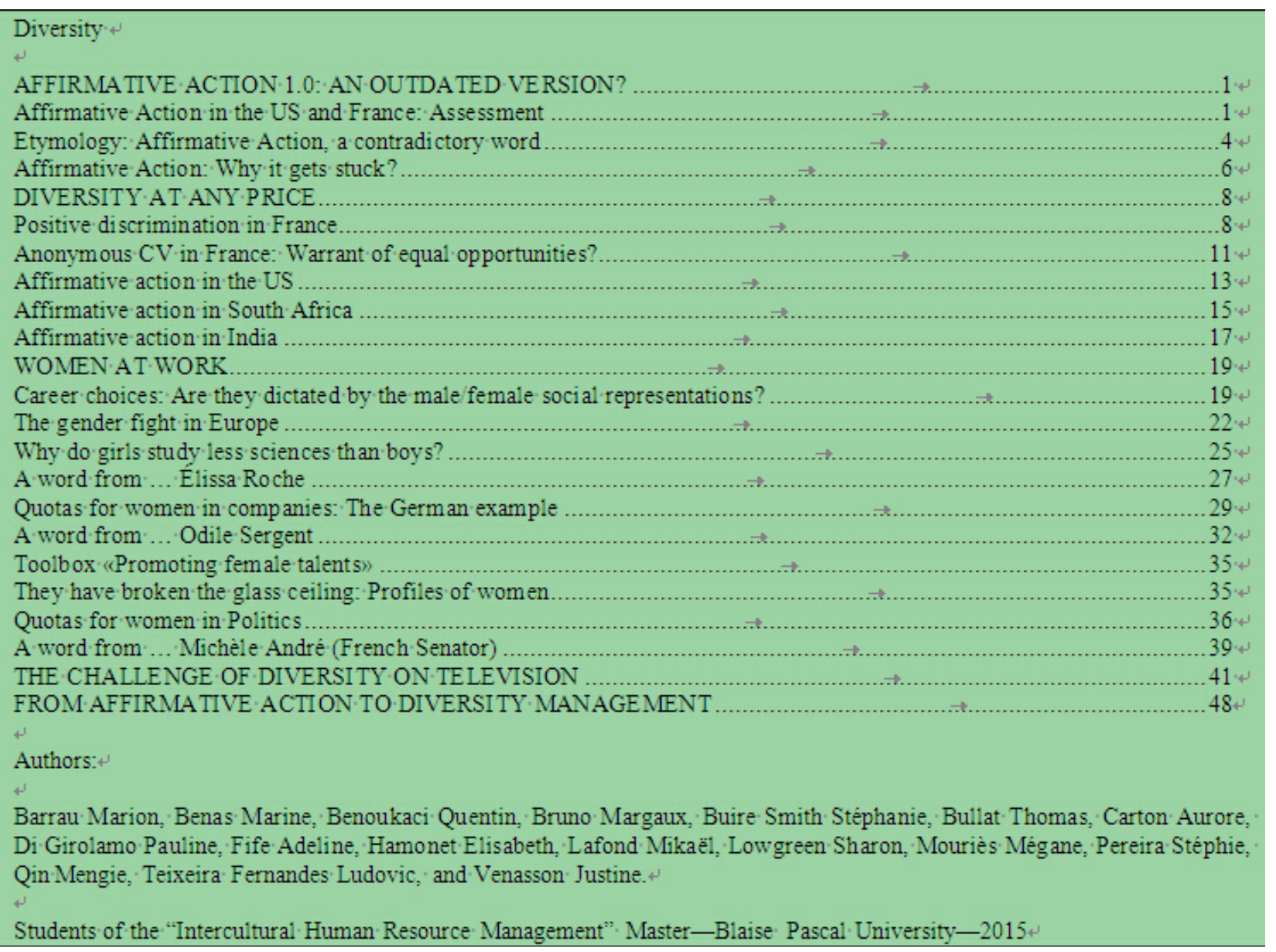

Figure 6. Summary of the brochure about diversity.

\section{Conclusion}

This article is an attempt to define a new strategy in terms of pedagogy as implemented at master's level classes. The ideas here above presented try to promote a new approach that can be useful in conferences because the everlasting debates are deeply rooted in antagonisms between two points of view. The first is based on the law and its enactment, the other is on the (would-be) paradoxical effects of the law in the way it affects the Americans of all the walks of life.

This work is also an attempt to define a new role for teachers who will inevitably evolve with the rapid developments of ICT and its consequences in terms of defining what makes sense and what is related to sensitivity. We had confirmation of this in the way our students used these technologies in order to do their work. In that case, the Internet as an extraordinarily vast field of opportunities, gave them the tools to meet the challenges presented in class. 


\section{References}

Bernard-Weil, E. (1992). Agonistic antagonistic systemics: An introduction to bilateral-and paradoxically unilateral-strategies. Kybernetes, 21(4), 47-66.

Callon, M. (1986). Some elements of a sociology of translation: Domestication of the scallops and the fishermen of St. Brieuc Bay. Power, Action, and Belief: A New Sociology of Knowledge, 32, 196-223.

Ezra, M. (Ed.). (2013). The economic civil rights movement, African Americans and the struggle for economic power. New York, N.Y.: Routledge Studies.

Gardner, H. (2011). Frames of mind: The theory of multiple intelligences (3rd ed.). New York, N.Y.: Basic Books.

Graham, H. D. (1992). Civil rights and the presidency, race and gender in American politics, 1960-1972. Oxford, U.K.: Oxford University Press.

Hampton. H. (1986). Eyes on the prize. Alexandria, V.A.: Public Broadcasting System.

Klarman, M. (2004). From Jim Crow to civil rights: The Supreme Court and the struggle for racial equality. Oxford, U.K.: Oxford University Press.

Kull, A. (1994). The color-blind constitution (Paperback ed.). Cambridge, M.A.: Harvard University Press.

Latour, B. (1984). Why has critique run out of steam? From matters of fact to matters of concern. Critical Inquiry, 30(2), $225-248$.

Latour, B. (2005). Reassembling the social. London, U.K.: Oxford.

Loevy, R. (1997). The Civil Rights Act of 1964: The passage of the law that ended racial segregation. Albany, N.Y.: State University of New York Press.

Mann, R. (1996). The walls of Jericho: Lyndon Johnson, Herbert Humphrey, Richard Rusell and the struggle for civil rights. New York, N.Y.: Harcourt Brace.

Risen, C. (2014). The bill of the century, the epic battle of the civil rights act. New York, N.Y.: The Bloomsbury Press.

Roberts, G., \& Klibanoff, H. (2008). The race beat, the press, the civil rights struggle and the awakening of a nation. New York, N.Y.: Vintage Books.

Venturini, T. (2010). Diving in magma: How to explore controversies with Actor-Network Theory. Public Understanding of Science, 19(3), 258-273. 